Louisiana State University

LSU Digital Commons

6-1-2007

\title{
Molecular phylogeny of the scincid lizards of New Caledonia and adjacent areas: Evidence for a single origin of the endemic skinks of Tasmantis
}

\author{
Sarah A. Smith \\ Villanova University \\ Ross A. Sadlier \\ Australian Museum \\ Aaron M. Bauer \\ Villanova University \\ Christopher C. Austin \\ Louisiana State University \\ Todd Jackman \\ Villanova University
}

Follow this and additional works at: https://digitalcommons.Isu.edu/biosci_pubs

\section{Recommended Citation}

Smith, S., Sadlier, R., Bauer, A., Austin, C., \& Jackman, T. (2007). Molecular phylogeny of the scincid lizards of New Caledonia and adjacent areas: Evidence for a single origin of the endemic skinks of Tasmantis. Molecular Phylogenetics and Evolution, 43 (3), 1151-1166. https://doi.org/10.1016/j.ympev.2007.02.007 


\title{
Molecular phylogeny of the scincid lizards of New Caledonia and adjacent areas: Evidence for a single origin of the endemic skinks of Tasmantis
}

\author{
Sarah A. Smith ${ }^{\mathrm{a}, *}$, Ross A. Sadlier ${ }^{\mathrm{b}}$, Aaron M. Bauer ${ }^{\mathrm{a}}$, \\ Christopher C. Austin ${ }^{\text {c }}$, Todd Jackman ${ }^{\text {a }}$ \\ a Department of Biology, Villanova University, 800 Lancaster Avenue, Villanova, PA 19085, USA \\ ${ }^{\mathrm{b}}$ Section of Herpetology, Australian Museum, 6 College Street, Sydney 2000, NSW, Australia \\ ${ }^{\mathrm{c}}$ Museum of Natural Science, 119 Foster Hall, Louisiana State University, Baton Rouge, LA 70803, USA
}

Received 16 June 2006; revised 21 January 2007; accepted 8 February 2007

Available online 16 February 2007

\begin{abstract}
We use $\sim 1900$ bp of mitochondrial (ND2) and nuclear (c-mos and Rag-1) DNA sequence data to recover phylogenetic relationships among 58 species and 26 genera of Eugongylus group scincid lizards from New Caledonia, Lord Howe Island, New Zealand, Australia and New Guinea. Taxon sampling for New Caledonian forms was nearly complete. We find that the endemic skink genera occurring on New Caledonia, New Zealand and Lord Howe Island, which make up the Gondwanan continental block Tasmantis, form a monophyletic group. Within this group New Zealand and New Zealand + Lord Howe Island form monophyletic clades. These clades are nested within the radiation of skinks in New Caledonia. All of the New Caledonian genera are monophyletic, except Lioscincus. The Australian and New Guinean species form a largely unresolved polytomy with the Tasmantis clade. New Caledonian representatives of the more widespread genera Emoia and Cryptoblepharus are more closely related to the non-Tasmantis taxa than to the endemic New Caledonian genera. Using ND2 sequences and the calibration estimated for the agamid Laudakia, we estimate that the diversification of the Tasmantis lineage began at least 12.7 million years ago. However, using combined ND2 and c-mos data and the calibration estimated for pygopod lizards suggests the lineage is 35.4-40.74 million years old. Our results support the hypothesis that skinks colonized Tasmantis by over-water dispersal initially to New Caledonia, then to Lord Howe Island, and finally to New Zealand.
\end{abstract}

(C) 2007 Elsevier Inc. All rights reserved.

Keywords: Scincidae; Phylogeny; New Caledonia; Tasmantis; Lord Howe Island; New Zealand; Biogeography

\section{Introduction}

The French Pacific island territory of New Caledonia forms part of a large continental block, Tasmantis (Fig. 1), that detached from the eastern margin of Gondwanaland 80-90 MYA (Holloway, 1979; Kroenke, 1984; Kroenke, 1996; Otte and Rentz, 1985; Swenson et al., 2001). The other major emergent component of Tasmantis is New

\footnotetext{
* Corresponding author. Present address: Ecology and Evolution, Stony Brook University, Stony Brook, NY 11794, USA. Fax: +61 889209222 (Australia).

E-mail address: sarah.a.smith@villanova.edu (S.A. Smith).
}

Zealand, which is connected to New Caledonia via the submarine Norfolk Ridge, today emergent only at Norfolk Island. To the west, the Lord Howe Rise, including Lord Howe Island and its satellite islets, also constitutes part of Tasmantis. During portions of the Tertiary, emergent areas of the Norfolk Ridge and Lord Howe Rise were more extensive than today, but there is no consensus as to if or when direct land connections between New Caledonia and New Zealand existed (Swenson et al., 2001). If such linkages were once present, they were certainly sundered by the Oligocene Marine trangressions that inundated New Zealand during the Oligocene (Cooper and Millener, 1993) and may have submerged all or most of New Caledonia 


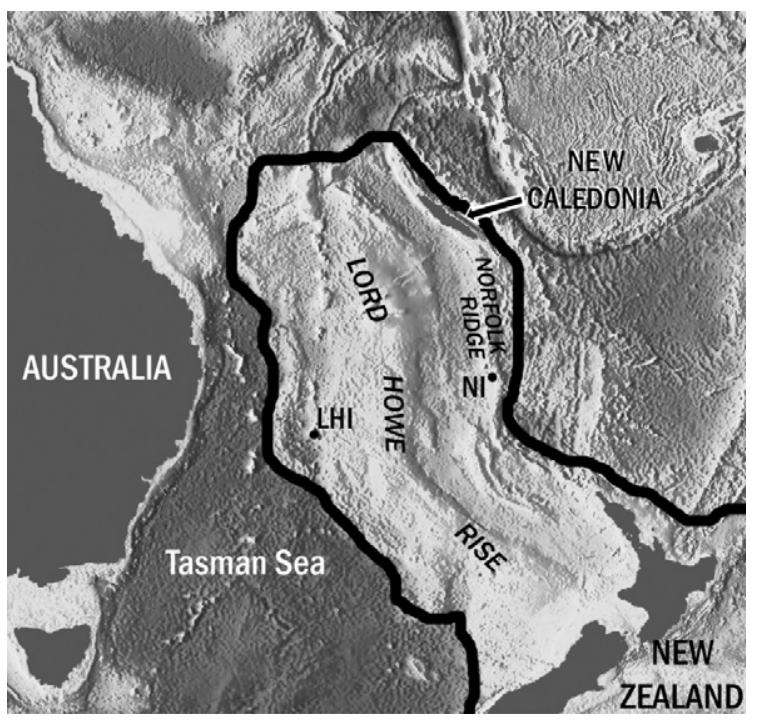

Fig. 1. Bathymetric map of the southwest Pacific Ocean showing areas discussed in this paper. LHI, Lord Howe Island; NI, Norfolk Island. Thick black line represents the approximate boundaries of the Tasmantis block. The southern limits of this block extend to the Auckland Islands and Campbell Island, while in the east they reach the Chatham Islands. Map modified from ETOPO2 2 min relief map, National Geophysical Data Center, National Oceanic and Atmospheric Administration, U.S. Department of Commerce.

(Cluzel et al., 2001; Murienne et al., 2005). Although some reconstructions suggest that New Caledonia may have been submerged for the first 30-50 Myr of its post-Gondwanan history (Hall, 1997), close links with New Zealand, whether direct or via island steppingstones, have long been supported by both geological data (Raven and Axelrod, 1972; Coleman, 1980; Stevens, 1980; Stevens, 1989) and biological distribution patterns (Penny, 1975; Winterbourn, 1980; Bauer, 1990; Swenson et al., 2001; Buckley et al., 2002).

Partly as the result of their long and complex geological and climatic histories and concomitant opportunities for cladogenesis and anagenesis, the terrestrial biota of the two largest components of Tasmantis, New Zealand and New Caledonia, exhibit high levels of species richness and endemism (Holloway, 1979; Daugherty et al., 1993; Chazeau, 1993). This is particularly true of New Caledonia, which has been identified as one of the world's hotspots of tropical biodiversity (Myers, 1988, 1990; Mittermeier et al., 1996; Lowry, 1998; Myers et al., 2000; Lowry et al., 2004). New Caledonia is especially significant as a center of floral endemism (Virot, 1956; Morat, 1993; Morat et al., 1986; Jaffré et al., 1998), and it supports a number of archaic forms, including Amborella, the sister group to all other flowering plants (Brown, 1999). Although less well studied than the flora, the terrestrial and freshwater fauna is also extremely rich and in some groups endemism reaches $100 \%$ (Chazeau, 1993; Platnick, 1993; Séret, 1997; Haase and Bouchet, 1998). In contrast, species diversity in the neighboring islands comprising the geologically younger and more heterogeneous Outer Melanesian Arc (extending from New Guinea east to the Tonga Trench and including the Admi- ralty, Bismarck, and Solomon Islands as well as Vanuatu, Fiji and Tonga) decreases rapidly from west to east and inter-island faunal similarity, especially at the generic level, is high (Polhemus, 1996; Bauer and Sadlier, 2000). Among vertebrates lizards constitute the most diverse and highly endemic component of the New Caledonian fauna (Bauer, 1989, 1999; Bauer and Sadlier, 2000), although all endemic taxa are representatives of either the gekkotan family Diplodactylidae or the scincid subfamily Lygosominae.

The earliest descriptions of New Caledonian scincids (Peters, 1869, 1879; Bavay, 1869; Günther, 1872, 1873; Bocage and Barboza, 1873) placed most species in the large and widespread genera Eumeces, Lygosoma and Euprepes, although several new genera were proposed for some New Caledonian species (the diminutive fossorial skinks Anotis Bavay, 1869 and Nannoscincus Günther, 1872; the large, keeled-scaled skinks Tropidoscincus Bocage and Barboza, 1873; and Sauroscincus Peters, 1879; and Lioscincus Bocage and Barboza, 1873). Boulenger (1887) relegated the majority of New Caledonian skinks to the cosmopolitan Lygosoma in Catalogue of Lizards in the British Museum, the first major treatise incorporating the New Caledonian lizard fauna. Likewise, the monograph of Roux (1913) dealing with the fauna of New Caledonia placed all 19 species and subspecies of skinks then recognized into Lygosoma (with the exception of the shore skink Ablepharus boutoni-now Cryptoblepharus novocaledonicus). Smith (1937) in reviewing the groups within Lygosoma basically retained this taxonomy, but explicitly recognized several infrageneric sections. Most New Caledonian taxa fell into his Section Leiolopisma, although one (deplanchei) was placed in the Section Sphenomorphus, one (cyanura) was allocated to the genus Emoia and one (garnieri) to the subgenus Riopa (Eugongylus). Mittleman (1952) reallocated skink taxa at the generic level within the subfamily Lygosominae and recognized seven genera that included New Caledonian species (Anotis, Cryptoblepharus, Emoia, Tachygyia, Lampropholis, Sphenomorphus and Leiolopisma), all of which also occurred extralimitally.

Greer (1970) provided the first modern review of the Scincidae, recognizing four subfamilies, one of whichthe nearly cosmopolitan Lygosominae - included all of the New Caledonian skinks. Within the lygosomines, Greer (1974) subsequently reevaluated relationships among the extensive assemblage of species that made up the genus Leiolopisma and its allies. His Group II included all of the New Caledonian taxa, which were placed among the genera Leiolopisma (most species), Anotis, Emoia, Cryptoblepharus, and Phoboscincus (newly erected to accommodate the two largest species, garnieri and bocourti).

Greer (1974) regarded the Group II lygosomines, subsequently renamed the Eugongylus group (Greer, 1979), to have been derived from "a Mabuya stock," based largely on shared primitive character states. Greer (1974) considered Phoboscincus to be closely allied to both Eugongylus (Halmahera through New Guinea to the Solomon Islands) and Tachygyia (Tonga). On the basis of distributional data, 
he regarded Tachygyia and Phoboscincus to be independently derived from a Eugongylus-like ancestor. He also postulated the origin of Cryptoblepharus from Emoia and of Emoia from Eugongylus or a Eugongylus-like ancestor, although without specific mention of the New Caledonian members of the former two genera. Greer (1974) regarded Anotis as a specialized genus derived from Leiolopisma with three species (gracilis, mariae, slevini) from New Caledonia and two (maccoyi, graciloides) from Australia, although he was unconvinced of its monophyly.

Böhme (1976) described the distinctive New Caledonian species Eugongylus haraldmeieri, which he regarded as intermediate between the giant Pacific Island skink genera Phoboscincus (New Caledonian) and Tachygyia (Tongan). On this basis he synonymized the two younger names with Eugongylus.

Sadlier (1986) comprehensively revised the New Caledonian scincids and accepted all of Greer's (1974) generic allocations outside of Leiolopisma proper, although Anotis spp. were transferred to Nannoscincus based on the preoccupation of the former name (Cogger, 1979; Czechura, 1981). Sadlier (1986) rejected Böhme's (1976) taxonomic conclusions regarding Phoboscincus and resurrected this genus, while establishing the monotypic Geoscincus to accommodate Eugongylus haraldmeieri. He also erected the monophyletic genera Caledoniscincus, Marmorosphax and Sigaloseps, and resurrected Tropidoscincus Bocage and Barboza, 1873 to accommodate most of the New Caledonian species formerly assigned to Leiolopisma, and described Graciliscincus for a distinctive newly discovered fossorial skink. Subsequently, the remaining morphologically primitive species that lack the apomophies that would allow placement within any existing genus were transferred to the genus Lioscincus (type species Lioscincus steindachneri Bocage and Barboza, 1873) (Bauer and Sadlier, 1993), the only available generic name for any of the constituent species. However, the probable paraphyly or polyphyly of Lioscincus has been acknowledged (Bauer and Sadlier, 1993, 2000; Sadlier et al., 1998, 2004; Sadlier and Bauer, 1999b).

In the last decade extensive field work by the authors and their colleagues in New Caledonia has resulted in the discovery of numerous additional skink species, including highly apomorphic taxa that have been allocated to the new monotypic genera Simiscincus Sadlier and Bauer, 1997a; Lacertoides Sadlier et al., 1997 and Kanakysaurus Sadlier et al., 2004. Most recently, Lygosoma euryotis Werner, 1909 (initially placed in Marmorosphax by Sadlier, 1986) has been removed to a new genus, Celatiscincus Sadlier et al., 2006; which it shares with a newly recognized sister species. Thus, the present skink fauna of New Caledonia includes 49 species in 15 genera.

The genera Celatiscincus, Geoscincus, Graciliscincus, Kanakysaurus, Lacertoides, Lioscincus, Marmorosphax, Nannoscincus, Phoboscincus, Sigaloseps, Simiscincus, and Tropidoscincus are strictly endemic to New Caledonia, chiefly on the Grande Terre, but also on the neighboring
Loyalty Islands, Isle of Pines and smaller satellite islands. Note that Nannoscincus has only recently been restricted to the New Caledonian species, and the Australian species Saiphos maccoyi Lucas \& Frost, 1894 (formerly regarded as part of Nannoscincus) is now assigned to the genus Anepischetosia (Sadlier et al., 2006). Caledoniscincus is nearly endemic, with a single species, (C. atropunctatus), extending northeastwards to the southern islands of Vanuatu (Medway and Marshall, 1975; Bauer and Sadlier, 2000). Cryptoblepharus novocaledonicus is a putatively endemic species that is representative of a relatively speciose genus occurring elsewhere in Australia and on numerous islands in the Pacific and Indian Oceans. Finally, Emoia is a southeast Asian and Pacific genus with one widespread species $(E$. cyanura) and one endemic species (E. loyaltyensis) in the Loyalty Islands.

Recently, molecular approaches have been widely applied to problems of lygosomine relationships, however, most of these broader analyses have not included even a single member of the New Caledonian Eugongylus group taxa (Honda et al., 1999, 2000, 2003; Whiting et al., 2003; Brandley et al., 2005) and the only published molecular phylogeny using New Caledonian taxa employed only six taxa (Sadlier et al., 2004). Although alternative higher order relationships among skinks as a whole have been proposed (e.g., Whiting et al., 2003; Brandley et al., 2005) and the monophyly of the Lygosominae has been called into question, there is strong support for the monophyly of the Eugongylus group and for all lygosomines exclusive of the Sphenomorphus group (Honda et al., 2000, 2003; Whiting et al., 2003).

The monophyly of the Eugongylus group has been corroborated by a variety of studies (Donnellan, 1985; Greer, 1989, 1990; Hutchinson, 1993; Hutchinson and Donnellan, 1993; Hutchinson et al., 1990; Honda et al., 2000, 2003; Smith, 2001), although relationships within the group remain contentious. To date, however, limited morphological, immunological and molecular sequence approaches have failed to clarify relationships within New Caledonia, or between New Caledonia and other neighboring radiations. Hutchinson et al. (1990), based on unpublished data from micro-complement fixation, implied that New Caledonian members of the Eugongylus group were not particularly closely related to their New Zealand or Australian counterparts, although all formed part of a monophyletic Eugongylus group radiation in the Australian region. Both Hardy (1977) and Hickson et al. (2000) postulated that the New Caledonian skinks were perhaps the closest relatives of those on New Zealand, but they lacked comparative material to test this hypothesis.

A number of largely phenetic working hypotheses regarding New Caledonian skinks have been proposed. These include the close relationshsip of Phoboscincus and Geoscincus (Böhme, 1976; Börner, 1980), Graciliscincus to Simiscincus (Sadlier and Bauer, 1997b), and Tropidoscincus and Lacertoides to Lioscincus maruia and L. tillieri (Sadlier et al., 1997; Sadlier and Bauer, 1999b). Böhme (1979) also 
remarked on the clear similarity of Leiolopisma greeri to $L$. nigrofasciolatus and their affinity has been accepted by subsequent authors (Sadlier, 1986; Bauer and Sadlier, 2000).

Relationships among some species of Caledoniscincus have been investigated using allozymes (Sadlier et al., 1999) and a revision of Emoia (Brown, 1991) suggests that the two New Caledonian species are not especially closely related to one another. Sadlier (1990; Sadlier et al., 2002) recognized the New Caledonian members of Nannoscincus as a monophyletic group, identifying two species groups on the basis of morphological data. Most recently, Sadlier et al. (2004) described Lioscincus vivae and presented both morphological and molecular evidence for its close relationship to L. steindachneri. Although monophyletic subunits of the New Caledonian skink fauna can be readily identified on the basis of derived features of scalation, osteology and soft anatomy, such data sets have proved ineffective at elucidating patterns of relationship among these highly distinctive clades.

In this study, we use mitochondrial and nuclear DNA sequence data to address the following questions: (1) do the scincid lizards of New Caledonia belong to a single monophyletic clade and, if so, what is the relationship between this clade and skinks in other Tasmantis landmasses? (2) are the New Caledonian skink genera as currently constituted monophyletic? and (3) how are genera within New Caledonia related?

\section{Materials and methods}

\subsection{Taxon sampling}

Sequences were obtained from representatives of all recognized species of New Caledonian scincid lizards except Geoscincus haraldmeieri, Phoboscincus bocourti, Lioscincus greeri and Nannoscincus exos (Table 1). Nannoscincus exos is a recently described form (Bauer and Sadlier, 2000; Sadlier et al., 2002) known from only a few specimens; $L$. greeri also remains known from only a few specimens and the remaining two taxa are known only from the types (although $P$. bocourti has recently been rediscovered on Ile Brosse, off of the Isle of Pines (Ineich, 2004)). Attempts to obtain sequence from the ethanol-preserved types of $G$. haraldmeieri and L. greeri were unsuccessful. Where possible we sampled two localities for each species. For widespread species, localities were chosen to represent as much of the species range as possible (Fig. 2).

Representative taxa from non-New Caledonian lineages were chosen from extralimital members of the Eugongylus group; and from other lineages of lygosomine skinks. Within the Eugongylus group we sampled several skinks from other components of Tasmantis: "Oligosoma" lichenigera from Lord Howe Island and three species of Oligosoma and one Cyclodina from New Zealand (c-mos and Rag-1 sequences for Lord Howe Island and New Zealand taxa are from Smith, 2001). The Australian genera Catula, Morethia, Menetia, Pseudemoia, Saproscincus, Lygisaurus,
Lampropholis, and Niveoscincus (one species each) were also sampled. Remaining Eugongylus group taxa included in the analysis were Leiolopisma telfairii from Round Island, Mauritius and New Guinean representatives of Eugongylus and Emoia. Outgroup taxa included Sphenomorphus, Eutropis (Mabuya), Apteryogodon, Panaspis, Tropidophorus and Tiliqua.

Tissue samples for New Caledonian taxa were obtained chiefly from our own field work and corresponding specimens have been deposited in the collections of the Australian Museum, Sydney (AMS) and California Academy of Sciences, San Francisco (CAS). Additional samples were obtained from Christopher C. Austin, Louisiana State University (CCA), Charles H. Daugherty, National Frozen Tissue Collection (NFTC) housed at Victoria University of Wellington, New Zealand (CD and FT), and the Zoologisches Forschungsinstitut und Museum A. Koenig, Bonn, Germany (ZFMK).

\subsection{DNA extraction, PCR amplification, and sequencing}

We included DNA sequence data from one mitochondrial and two nuclear genes, including the mitochondrial $\mathrm{NADH}$ dehydrogenase subunit 2 (ND2; $514 \mathrm{bp}$ ); and nuclear recombination activating gene 1 (Rag-1; $830 \mathrm{bp}$ ) and oocyte maturation factor (c-mos; $549 \mathrm{bp}$ ). DNA was extracted from liver tissue that had been frozen or stored in 95\% ethanol using the DNeasy kit (Qiagen). PCR was conducted using Eppendorf mastertaq. ND2 was amplified and sequenced using primers L4437b (Macey et al., 1997) and ND2r102 (Sadlier et al., 2004). Rag-1 primers were R13 from Groth and Barrowclough (1999) and an additional reverse primer G425 (primer sequence-5'-AAA GCA AGG ATA GCG ACA AGA G-3'; Smith, 2001). C-mos was amplified using G303 (primer sequence-5'-ATT ATG CCA TCM CCT MTT CC-3'; Saint) and G74 (Saint et al., 1998). Amplification conditions were: initial denaturation at $94^{\circ} \mathrm{C}$ for $2 \mathrm{~min}$, denaturation at $94^{\circ} \mathrm{C}$ for $45 \mathrm{~s}$, annealing at $52^{\circ} \mathrm{C}$ for $45 \mathrm{~s}$, and extension at $72{ }^{\circ} \mathrm{C}$ for $1 \mathrm{~min}$, for 34 cycles. Negative controls were run for all amplifications. Amplified products were purified using GFX PCR purification columns (Amersham Biosciences). Both strands of each PCR product were purified and sequenced using an ABI 373 or 3700 automated sequencer. GenBank accession numbers, are provided in Table 1.

\subsection{Phylogenetic analyses}

Alignment of sequences was performed using Clustal X.1.81 (Thompson et al., 1997) with default parameters (gap opening $=15$; gap extension $=6.666$; delay divergent sequences $=30 \%$; transition:transversion $=50 \%$ ), with adjustments by eye using Se-Al v1.0 (Rambaut, 1995). A few taxa lacked data for one or more genes (Table 1), however recent simulations (Wiens, 2003; Phillipe et al., 2004) and analyses of empirical data sets (Phillipe et al., 2004; Driskell et al., 2004; Wiens et al., 2005) suggest that 
Table 1

Specimens sampled for this study

\begin{tabular}{|c|c|c|c|c|c|}
\hline \multirow{2}{*}{$\begin{array}{l}\text { Taxon } \\
\text { Eugongylus group }\end{array}$} & \multirow[t]{2}{*}{ Specimen } & \multirow[t]{2}{*}{ Locality } & \multicolumn{3}{|c|}{ GenBank Accession Nos. } \\
\hline & & & ND2 & Rag-1 & C-mos \\
\hline \multicolumn{6}{|l|}{ New Caledonia } \\
\hline Caledoniscincus aquilonius & AMS R161247 & (5) Dôme de Tiébaghi & DQ675194 & DQ675274 & DQ675399 \\
\hline Caledoniscincus atropunctatus & CAS231910 & (21) NW of Moindou & DQ675195 & DQ675275 & DQ675400 \\
\hline Caledoniscincus atropunctatus & AMS R161083 & (2) Île Art, Îles Belep & DQ675196 & DQ675276 & DQ675401 \\
\hline Caledoniscincus auratus & AMS R157911 & (11) Tia & DQ675197 & DQ675277 & DQ675402 \\
\hline Caledoniscincus austrocaledonicus & AMS R1161186 & (16) Creek Hervouët & DQ675198 & DQ675278 & DQ675403 \\
\hline Caledoniscincus austrocaledonicus & CAS 231888 & (32) Île des Pins & DQ675199 & DQ675279 & DQ675404 \\
\hline Caledoniscincus chazeaui & AMS R138515 & (6) Koulnoué & DQ675272 & - & - \\
\hline Caledoniscincus festivus & AMS R161882 & (28) Monts Kwa Ne Mwa & DQ675200 & DQ675280 & DQ675405 \\
\hline Caledoniscincus haplorhinus & EBU15039 & (3) Maa Bwén, Île Baaba & DQ675201 & DQ675281 & DQ675406 \\
\hline Caledoniscincus orestes & AMS R149926 & (18) Néoua area, Mé Adéo & DQ675202 & DQ675282 & DQ675407 \\
\hline Caledoniscincus renevieri & AMS R165851 & (14) Mt. Aoupinié & DQ675268 & DQ675348 & - \\
\hline Caledoniscincus terma & CAS198680 & (4) Mt. Mandjélia & DQ675271 & - & - \\
\hline Celatiscincus euryotis & AMS R138574 & (32) Île des Pins & DQ675204 & DQ675284 & DQ675409 \\
\hline Celatiscincus similis & AMS R153504 & (8) Tsiba & DQ675203 & DQ675283 & DQ675408 \\
\hline Cryptoblepharus novocaledonicus & AMS R165930 & (32) Île des Pins & DQ675205 & DQ675285 & DQ675410 \\
\hline Emoia cyanura & AMS R163421 & (33) Maré, Îles Loyauté & DQ675263 & DQ675343 & - \\
\hline Emoia loyaltiensis & AMS R163417 & (33) Maré, Îles Loyauté & DQ675206 & DQ675286 & DQ675411 \\
\hline Graciliscincus shonae & AMS R147856 & (27) Mt. Koghis & DQ675254 & DQ675334 & DQ675391 \\
\hline Graciliscinus shonae & AMS R165813 & (25) Mt. Ouin & DQ675207 & DQ675287 & DQ675412 \\
\hline Kanakysaurus viviparus & AMS R161232 & (5) Dôme de Tiébaghi & DQ675208 & DQ675288 & DQ675413 \\
\hline Kanakysaurus viviparus & AMS R161299 & (1) Île Pott, Îles Belep & DQ675209 & DQ675289 & DQ675349 \\
\hline Lacertoides pardalis & CAS 205483 & (31) Kwa Néie & DQ675210 & DQ675290 & DQ675350 \\
\hline Lacertoides pardalis & AMS R148051 & (31) Kwa Néie & DQ675211 & DQ675291 & DQ675351 \\
\hline Lioscincus maruia & AMS R163164 & (11) Plateau de Tia & DQ675213 & DQ675293 & DQ675353 \\
\hline Lioscincus maruia & AMS R149897 & (18) Mé Adéo & DQ675214 & DQ675294 & DQ675354 \\
\hline Lioscincus nigrofasciolatus & AMS R149334 & (7) Mt. Panié & DQ675215 & DQ675295 & DQ675355 \\
\hline Lioscincus nigrofasciolatus & AMS R138624 & (32) Île des Pins & DQ675216 & DQ675296 & DQ675356 \\
\hline Lioscincus novocaledonicus & AMS R166364 & (19) Bourail & DQ675251 & DQ675331 & - \\
\hline Lioscincus novocaledonicus & AMS R166367 & (19) Bourail & DQ675252 & DQ675332 & - \\
\hline Lioscincus steindachneri & AMS R149418 & (14) Mt. Aoupinié & DQ675217 & DQ675297 & DQ675357 \\
\hline Lioscincus steindachneri & AMS R149890 & (18) Mé Adéo & DQ675218 & DQ675298 & DQ675358 \\
\hline Lioscincus tillieri & AMS R148013 & (26) Mt. Mou & DQ675219 & DQ675299 & DQ675359 \\
\hline Lioscincus tillieri & AMS R148037 & (24) Mt. Vulcain & DQ675220 & DQ675300 & DQ675360 \\
\hline Lioscincus viviae & CAS 226163 & (12) Kopéto & DQ675221 & DQ675301 & DQ675361 \\
\hline Marmorosphax montana & AMS R165922 & (25) Mt. Ouin & DQ675226 & DQ675306 & DQ675366 \\
\hline Marmorosphax montana & AMS R165802 & (25) Mt. Ouin & DQ675255 & DQ675335 & DQ675392 \\
\hline Marmorosphax sp. nov. 1 & AMS R165973 & (9) Mt. Taom & DQ675224 & DQ675304 & DQ675364 \\
\hline Marmorosphax sp. nov. 2 & AMS R163197 & (15) Boulinda & DQ675225 & DQ675305 & DQ675365 \\
\hline Marmorosphax tricolor & CAS 214451 & (27) Mt. Koghis & DQ675227 & DQ675307 & DQ675367 \\
\hline Marmorosphax tricolor & AMS R163178 & (15) Boulinda & DQ675223 & DQ675303 & DQ675363 \\
\hline Nannoscincus garrulus & AMS R163453 & (23) Pic Ningua & DQ675261 & DQ675341 & - \\
\hline Nannoscincus garrulus & CAS 226166 & (23) Pic Ningua & DQ675262 & DQ675342 & - \\
\hline Nannoscincus gracilis & AMS R144351 & (22) Sarraméa & DQ675229 & DQ675309 & DQ675369 \\
\hline Nannoscincus gracilis & AMS R149892 & (18) Mé Adéo & DQ675233 & DQ675313 & DQ675373 \\
\hline Nannoscincus greeri & CAS 231942 & (10) Nèmèrétina & DQ675230 & DQ675310 & DQ675370 \\
\hline Nannoscincus hanchisteus & AMS R149355 & (17) Pindaï & DQ675270 & - & - \\
\hline Nannoscincus humectus & AMS R149498 & (13) Forêt Plate & DQ675269 & - & - \\
\hline Nannoscincus mariei & AMS R135111 & (27) Mt. Koghis & DQ675231 & DQ675311 & DQ675371 \\
\hline Nannoscincus mariei & AMS R146484 & (26) Mt. Mou & DQ675232 & DQ675312 & DQ675372 \\
\hline Nannoscincus sleveni & AMS R147879 & (20) Plateau de Dogny & DQ675256 & DQ675336 & - \\
\hline Phoboscincus garnieri & AMS R146293 & (32) Île des Pins & DQ675236 & DQ675316 & DQ675376 \\
\hline Phoboscincus garnieri & AMS R151964 & (29) Mt. Dore & DQ675237 & DQ675317 & DQ675377 \\
\hline Sigaloseps deplanchei & AMS R148065 & (30) Plaine des Lacs & DQ675238 & DQ675318 & DQ675378 \\
\hline Sigaloseps ruficauda & AMS R146482 & (26) Mt. Mou & DQ675239 & DQ675319 & DQ675379 \\
\hline Simiscincus aurantiacus & AMS R144356 & (27) Mt. Koghis & DQ675250 & DQ675330 & DQ675389 \\
\hline Tropidoscincus aubrianus & CAS 198661 & (32) Île des Pins & DQ675260 & DQ675340 & - \\
\hline Tropidoscincus boreus & AMS R163185 & (15) Boulinda & DQ675241 & DQ675321 & DQ675381 \\
\hline Tropidoscincus variabilis & AMS R161879 & (28) Monts Kwa Ne Mwa & DQ675242 & DQ675322 & DQ675382 \\
\hline Tropidoscincus variabilis & AMS R150734 & (29) Mt. Ouin & DQ675243 & DQ675323 & DQ675383 \\
\hline New genus & AMS R161182 & (9) Mt. Taom & DQ675193 & DQ675273 & DQ675398 \\
\hline
\end{tabular}


Table 1 (continued)

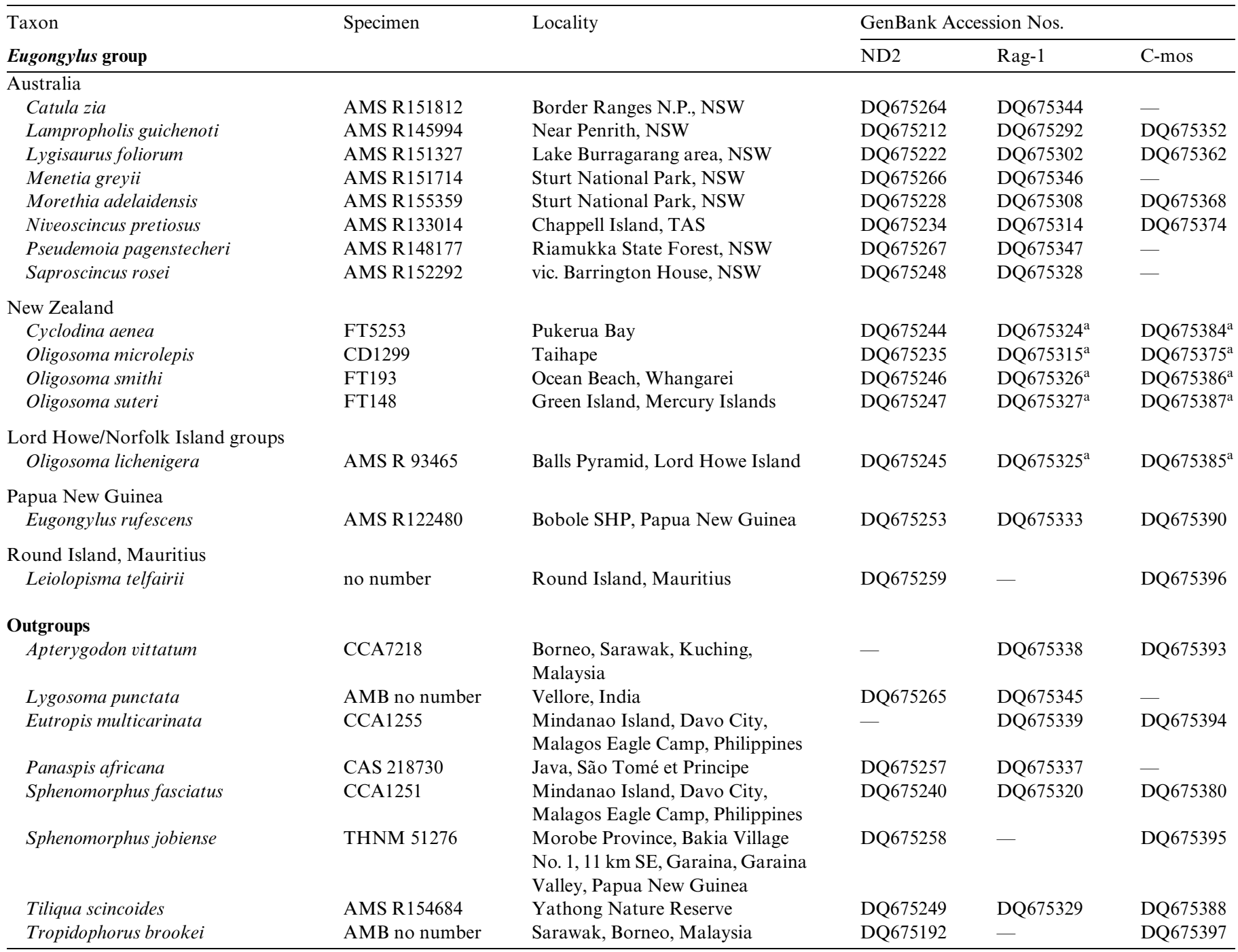

Parenthetical numbers in locality column correspond to localities plotted on Fig. 2.

a Data from Smith, 2001. Collection abbreviations are as follows: AMS, Australian Museum, Sydney; CAS, California Academy of Sciences, San Francisco; CCA, Christopher C. Austin, Louisiana State University; CD and FT, Charles H. Daugherty, Victoria University of Wellington, New Zealand (CD and FT); ZFMK, Zoologisches Forschungsinstitut und Museum A. Koenig, Bonn, Germany.

incomplete taxa can be accurately placed in phylogenetic analyses if the overall number of characters is high.

Data were analyzed using maximum parsimony and Bayesian methods. Each gene was initially analyzed separately to look for incongruence. Maximum parsimony analyses were implemented in PAUP* 4.0b10 (Swofford, 2002), using an heuristic search with tree-bisection-reconnection (TBR) branch swapping and 1000 random taxon-additionsequence replicates per search. Support for clades was evaluated using non-parametric bootstrapping (Felsenstein, 1985). Bootstrap analyses used 500 pseudoreplicates each with TBR branch swapping and 10 random addition sequence replicates per bootstrap pseudoreplicate. Bayesian analyses were implemented using MrBayes version 3.1.2 (Huelsenbeck and Ronquist, 2001). We used hierarchical likelihood-ratio tests (implemented in MrModeltest version 2.0; Nylander, 2004) to find the most appropriate model of sequence evolution for each gene. We investigated two par- titioning strategies for Bayesian analysis of this data. First, we used a single partition for each gene; second, we used three partitions for each gene representing first, second and third codon positions. In each case we used the model suggested by MrModeltest for all partitions within a gene. We used comparison of Bayes factors (Nylander et al., 2004) to determine which of these sampling strategies performs better (see Brandley et al., 2005; Wiens et al., 2005). Our analyses suggest that the best overall modeling and partitioning strategy for the combined molecular data uses the $\mathrm{GTR}+\mathrm{I}+\Gamma$ model for each codon position in ND2, and $\mathrm{HKY}+\Gamma$ for each codon position in Rag-1 and $\mathrm{HKY}+\mathrm{I}$ for each codon position in c-mos. We ran four replicate searches with $5.0 \times 10^{6}$ generations each, sampling every 1000 generations. Each analysis used four chains and default priors. Standard deviations of split frequencies and plots of log-likelihoods over time were examined for stationarity. All analyses appeared to reach stationarity before 


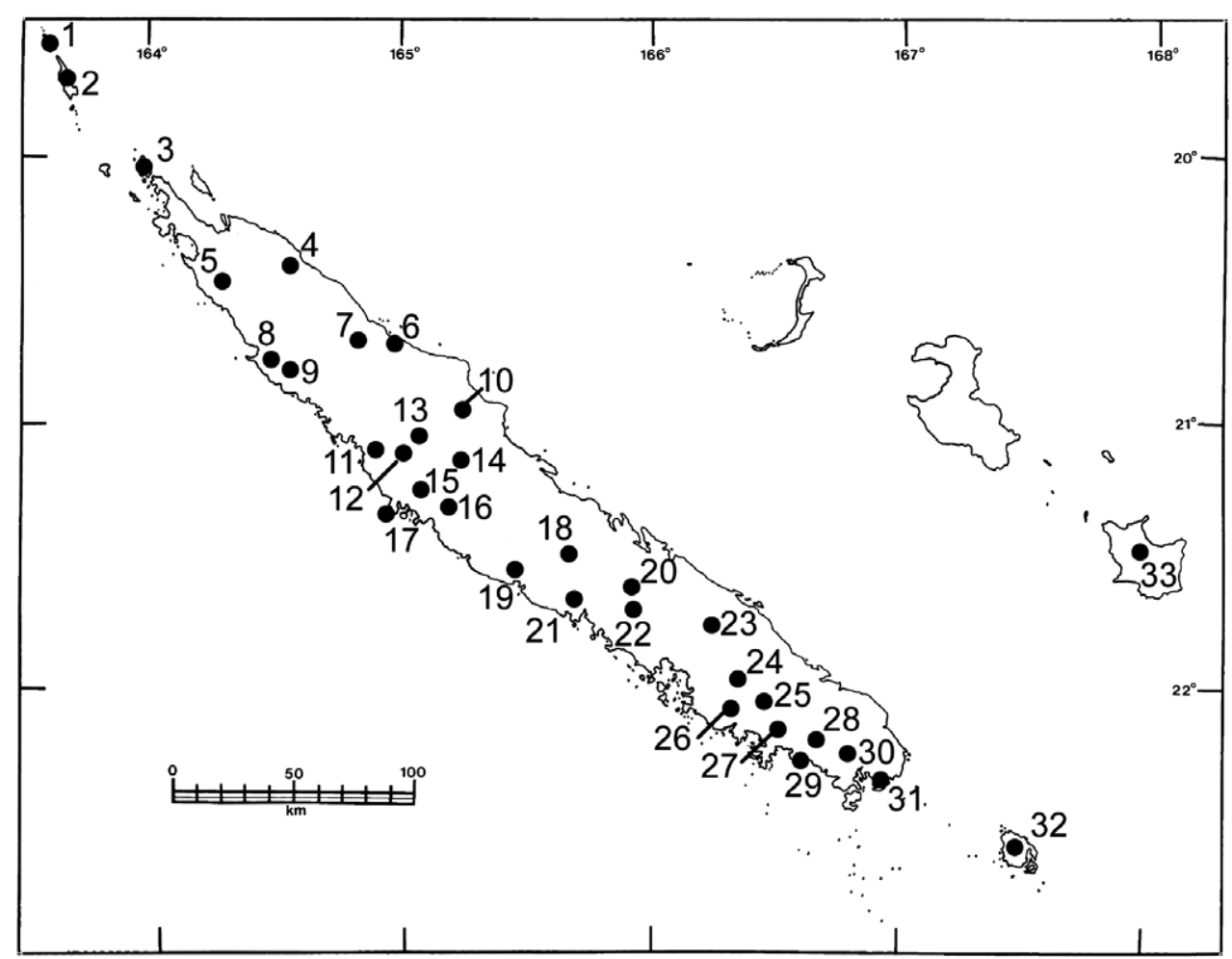

Fig. 2. Map of New Caledonia showing the collection localities of the skinks sampled. Numbered localities correspond to those listed in locality column of Table 1.

$1.0 \times 10^{6}$ generations, so the first 1000 trees were discarded as burn-in. Our alignments and treefiles have been submitted to TreeBase as study number S1702 and matrix accession numbers M3075-3077.

\subsection{Molecular clock considerations and hypothesis testing}

We estimated the age of the New Caledonian raditation using two different molecular clock calibrations. We used Macey et al.'s (1998) calibration for ND2 calculated from the agamid Laudakia, and Jennings et al's. (2003) calibration for combined ND2 and c-mos calculated from the pygopod Pygopus. We then used these estimates of the rate to calculate the age of divergence between selected lineages whose sister group relationships were well supported by both Bayesian and maximum parsimony analyses (see Section 3).

To estimate the age of the New Caledonian radiation using the calibration points for ND2 for the agamid lizard genus Laudakia (Macey et al., 1998), we reanalysed the Laudakia data using the $514 \mathrm{bp}$ fragment of ND2 that we used for our phylogenetic analysis. We estimated the average pairwise GTR distance between pairs of taxa at the nodes for which Macey et al. (1998) gave dates (1.5, 2.5, 3.5 and $9 \mathrm{Myr}$ old). We regressed the ages of these 4 nodes against the pairwise GTR distance; the slope of this regression is the rate of sequence evolution.

To estimate the age of the New Caledonian radiation using the calibration point for ND2 and c-mos for the pygopod lizard genus Pygopus (Jennings et al., 2003), we used $844 \mathrm{bp}$ of sequence for which we have both Pygopus and skink sequences. Using this data we calculated the GTR distance between $P$. orientalis and $P$. lepidopodus, and between $P$. orientalis and $P$. nigriceps. We then calculated the rate of sequence evolution when this node is 20 million years-old, and 23 million years-old (Jennings et al., 2003).

We tested whether our data can statistically reject alternative trees in which the New Caledonia and New Zealand taxa form reciprocally monophyletic clades. We tested alternative trees under maximum parsimony using the Templeton test (Templeton, 1983). Alternative trees are statistically rejected using Bayesian criteria if they do not occur in the $95 \%$ CI set of trees.

\section{Results}

Analyses of the three genes combined included a total of 1893 nucleotides, of which 961 were variable and 647 were parsimony informative. Analysing genes separately did not reveal any strongly supported incongruence so we discuss the results of analysis of the three genes combined. The Bayesian and maximum parsimony topologies were generally similar and all nodes strongly supported by maximum parsimony bootstrapping were also supported by high Bayesian posterior probabilities $\left(P_{\mathrm{p}}\right)($ Fig. 3$)$.

Relationships among the non-lygosomine outgroup taxa are well supported $\left(P_{\mathrm{p}} \geqslant 0.99\right)$. The two Sphenomorphus included in the analysis, $S$. fasciatus and $S$. jobiense, do not form a monophyletic group, nor do the Mabuya group taxa Apterygodon vittatum and Eutropis multicarinata. 


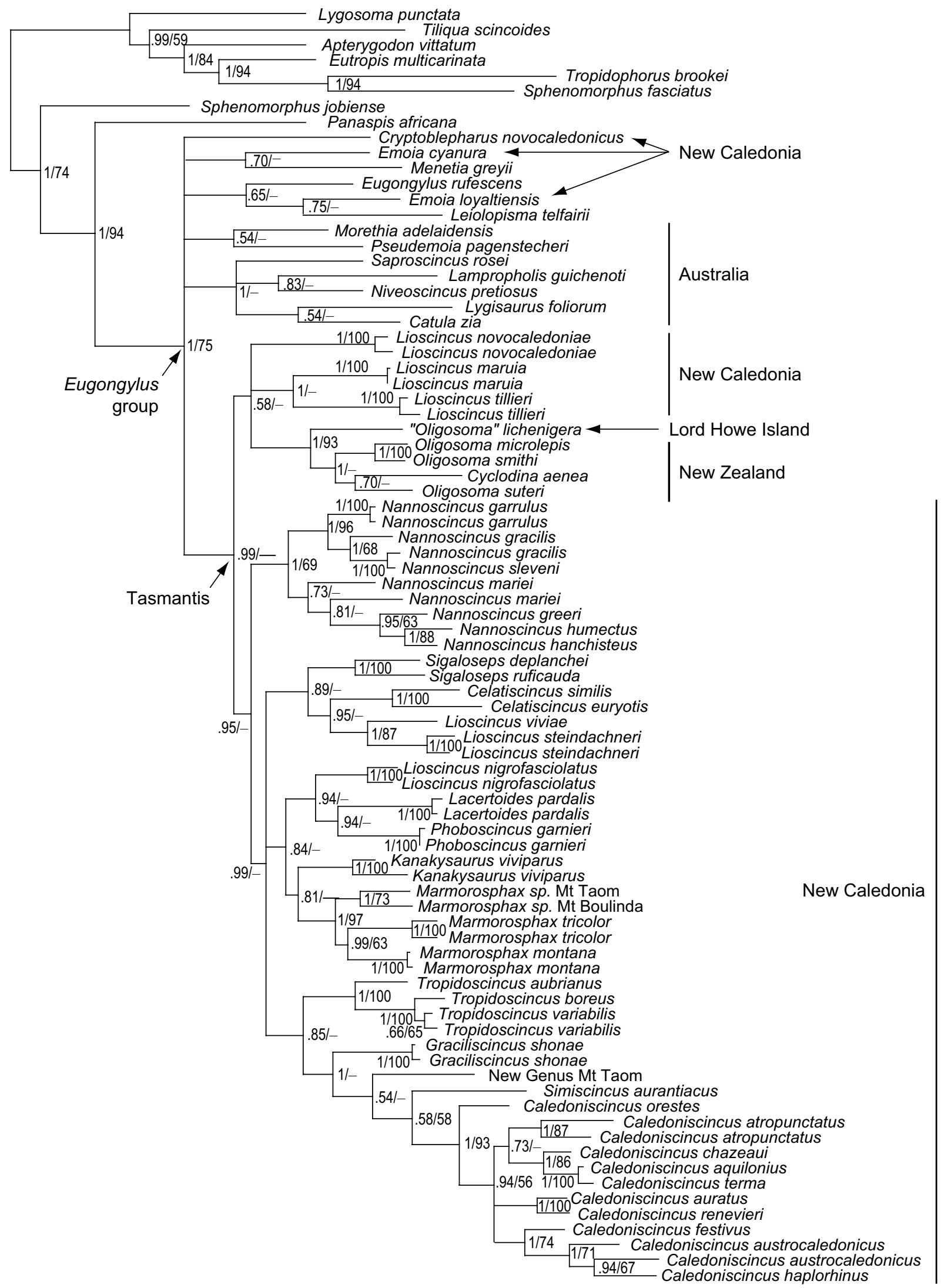

Fig. 3. Phylogeny based on combined, partitioned Bayesian analysis of one mitochondrial and two nuclear genes. Support values are shown as Bayesian posterior probability/bootstrap support values. Support less than $P_{\mathrm{p}} 0.50$ or bootstrap $50 \%$ are not shown. 
There is strong support $\left(P_{\mathrm{p}}=1.0\right)$ for both the Eugongylus group + Panaspis, and the Eugongylus group proper. Within the Eugongylus group there is a polytomy between the endemic Tasmantis genera and a series of clades including all remaining taxa, including the two New Caledonian area Emoia and Cryptoblepharus novocaledonicus as well as Leiolopisma telfairii and all Australian and New Guinea taxa sampled. There is strong support $\left(P_{\mathrm{p}}=1.0\right)$ for the clade including the Australian genera Saproscincus, Lygisaurus, Catula, Lampropholis, and Niveoscincus. Although branch length is short, there is strong support $\left(P_{\mathrm{p}}=0.99\right)$ for a large clade corresponding to the endemic Tasmantis genera of the Eugongylus group. The New Zealand skinks Oligosoma + Cyclodina form a monophyletic group embedded within the New Caledonian radiation, with the Lord Howe/Philip Island (a satellite of Norfolk Island) "Oligosoma" lichenigera well supported as its immediate sister group. The one species of Cyclodina included renders Oligosoma paraphyletic. The New Caledonian Lioscincus novocaledonicus and the well-supported species pair ( $L$. maruia $+L$. tillieri) form a polytomy with the New Zealand and Lord Howe/Phillip Island species, but there is no significant support for the larger clade incorporating all three of these lineages and we cannot reject the hypothesis that the New Zealand/Lord Howe clade is the sister group of a monophyletic New Caledonian lineage (309 trees with this topology are found in the 7596 trees in the $95 \%$ confidence interval from our Bayesian analysis and $P \geqslant 0.9219$ using maximum parsimony).

All remaining New Caledonian skinks are members of a clade within which all constituent genera except Lioscincus, and all species except Caledoniscincus austrocaledonicus, Nannoscincus mariei and N. gracilis have strong support. Nannoscincus is the sister group to all New Caledonian genera in this clade. The remaining taxa constitute a number of discrete subclades as follows: Lioscincus vivae + L. steindachneri together are the sister group to Celatiscincus; together these are the sister group of Sigaloseps. A second clade has the pattern ((Marmorosphax + Kanakysaurus) (Lioscincus nigrofasciolatus (Lacertoides + Phoboscincus))). Tropidoscincus is the sister group to a trichotomy consisting of Graciliscincus, Simiscincus + Caledoniscincus, and an undescribed species from Mt. Taom representing a new genus. However, support for intergeneric relationships within this clade, and particularly for the placement of Simiscincus and the new genus is lacking.

Our reanalysis of $514 \mathrm{bp}$ of Laudakia data using a GTR model of sequence evolution resulted in an estimate of the rate of sequence evolution for this section of ND2 of $1 \%$ per lineage per million years. This is higher than the $0.65 \%$ rate estimated by uncorrected distance for the $\sim 1700$ bp of mitochondrial sequence used by Macey et al. (1998). Using this rate, the age of the split between the New Caledonia + New Zealand linage and the Australian/New Guinea species is at least $12.7 \mathrm{Myr}$. The split between "Oligosoma" lichenigera and OligosomalCyclodina is $7.9 \mathrm{Myr}$.
The ages of these nodes recovered using Jennings et al. (2003)('s) calibration for pygopods is much older. The rate of molecular evolution for ND2 + c-mos is $0.49-0.57 \%$ per lineage per million years (using node ages of 23 and 20 millions years). Using this rate, the age of the split between the New Caledonia + New Zealand linage and the Australian/ New Guinea species is approximately $35.4-40.7 \mathrm{Myr}$. The split between "Oligosoma" lichenigera and Oligosomal Cyclodina is $19.9-22.9 \mathrm{Myr}$

\section{Discussion}

\subsection{Eugongylus group phylogeny}

Our results corroborate the monophyly of the Eugongylus group lygosomines (sensu Greer, 1979) as a whole and are thus consistent with all previous studies (Donnellan, 1985; Greer, 1989, 1990; Hutchinson, 1993; Hutchinson and Donnellan, 1993; Hutchinson et al., 1990; Honda et al., 2000, 2003; Smith, 2001; Reeder, 2003; Austin and Arnold, 2006). Greer (1979) demonstrated that the Mascarene species Leiolopisma telfairii shares a number of diagnostic features with taxa in the Eugongylus group (alpha palate with posteromedial processes on trailing edges of palatines, 11 premaxillary teeth, 28 presacral vertebrae), but excluded it from membership as at least some individuals retain pterygoid teeth (Arnold, 1980). However, our data suggest that Leiolopisma is, indeed, a member of the Eugongylus clade. The sister group relationship between Leiolopisma and some Emoia was also recovered with low support by Austin and Arnold (2006), although the weakly supported relationship between this clade and Eugongylus was not recovered in their analysis. We also found support for the relatively close relationship of the African Panaspis to the Eugongylus group, as previously proposed by Greer (1979) and Smith (2001). Greer (1974) suggested that the beta palate morphology had been independently derived from the alpha palate in two different lineages, a sub-Saharan African one including Panaspis, and an Australo-Papuan one including Lampropholis and its relatives. Greer (1979) subsequently favored a monophyletic group of beta palate skinks, his Lampropholis subgroup, but our limited data support his earlier interpretation.

Our sampling of Australian taxa is insufficient to draw any broad conclusions, but our results are largely consistent with those of previous authors. Greer (1979) placed Eugongylus group skinks into two subgroups, the Eugongylus and Lampropholis subgroups based chiefly on palatal morphology and later (Greer, 1989) diagnosed the Pseudemoia group (including the Lampropholis subgroup) on the basis of the derived presence of a fused atlantal arch. Hutchinson et al. (1990), proposed a number of new genera for the Australian Eugongylus group members based chiefly on immunological (MCF) data. Their allocation of taxa resulted in species with both distinct and fused atlantal arches in a redefined genus Pseudemoia, and as such is clearly at odds with Greers concept of the Pseudemoia 
group. Our data does not support the higher order relationships of Hutchinson et al. (1990), nor does it support Greer's (1989) Pseudemoia group in its entirety, as the Australian and New Caledonian members are not parts of the same monophyletic group. This would indicate that fusion of the atlantal arches of the first cervical vertebrae has evolved on at least two occasions within skinks. Our data does support the monophyly of the Australian members of Greer's (1979) Lampropholis subgroup (here represented by Saproscincus, Lygisaurus, Catula, Niveoscincus and Lampropholis; Fig. 3), and it appears that the beta palate of the Lampropholis subgroup has evolved within a more extensive alpha palate lineage, rendering the alpha palate group paraphyletic. However, because relationships between the Lampropholis clade and others within the Eugongylus group are poorly supported, we cannot reject the alternative hypothesis that Greer's (1979) Eugongylus subgroup is monophyletic.

\subsection{Tasmantis skinks}

In our analysis, the species belonging to the widespread Pacific region genera Cryptoblepharus (novocaledonicus) and Emoia (cyanura and loyaltiensis) are the only members of the New Caledonian skink fauna that do not form part of a monophyletic group also including the New Zealand skinks and "Oligosoma" lichenigera from the Lord Howe and Norfolk Island groups. The two New Caledonian species of Emoia (cyanura and loyaltiensis) do not occur on the New Caledonian mainland (Grande Terre), but are restricted to the neighboring Loyalty Islands. These two species belong to different lineages; E. loyaltiensis is a member of the samoensis group sensu Brown (1991) and weakly groups with Leiolopisma telfairii and Eugongylus rufescens in our analysis, whereas E. cyanura was weakly supported as the sister species to Menetia greyii among the taxa sampled. These results are consistent with Smith's (2001) suggestion that Emoia is non-monophyletic. The New Caledonian Cryptoblepharus (novocaledonicus) is widespread on the Grande Terre and on satellite islands where it occupies low elevation sites, chiefly in or near the high tide zone (Bauer and Sadlier, 1994; Bauer and Sadlier, 2000; Sadlier and Bauer, 1997a). It did not show close relationships to Emoia, Morethia, or Menetia, all of which have been proposed at different times as sharing affinities with Cryptoblepharus (Greer, 1974, 1980, 1989).

All remaining Eugongylus group taxa are part of a well supported clade representing the lineages of the Tasmantis islands: New Caledonia, Lord Howe, Norfolk Island and New Zealand. Within this group, the New Zealand skinks form a strongly supported clade. But within New Zealand Oligosoma is paraphyletic, with Cyclodina aenea embedded within it. Generic placement of the New Zealand skinks has had a history of progressive sub-division, somewhat contempory with the dismantling of the New Caledonian and Australian Leiolopisma species. Greer $(1974,1979)$ included all New Zealand skinks in Leiolopisma. Hardy (1977) rec- ognized those species with scaly or opaque lower eyelids as Cyclodina, and Patterson and Daugherty (1995) resurrected Oligosoma for the remaining New Zealand species of "Leiolopisma" (contra Cogger, 1992 who placed these species in Pseudemoia). Although the monophyly of New Zealand skinks has been implied (Hutchinson et al., 1990), Hickson et al. (2000) were unable to demonstrate this using their data from $12 \mathrm{~S}$ rRNA. Our results corroborate earlier findings that the New Zealand skinks are monophyletic (Smith, 2001), that Oligosoma smithi and O. microlepis are closely related, and that Cyclodina renders Oligosoma paraphyletic (Hickson et al., 2000; Smith, 2001). Even the most comprehensive phylogeny of New Zealand skinks to date (Smith, 2001) has only sampled about half of the recognized species, and all attempts have had poor support for at least parts of their resultant trees. Oligosoma is noted for its cryptic species (Patterson and Daugherty, 1990; Daugherty et al., 1990) and at least 22-23 Oligosoma and 7-8 species (some undescribed) of Cyclodina are currently recognized (Daugherty et al., 1994; Berry et al., 2003). Any conclusions regarding the phylogeny of New Zealand skinks will require more extensive taxon sampling and perhaps a broader range of genetic markers.

Our results support those of Smith (2001) with respect to the placement of "Oligosoma" lichenigera, which inhabits Philip Island and the Lord Howe group, as the sister group to the New Zealand skink clade. This isolated species had previously been hypothesized to be closely related to Oligosoma suteri (Towns, 1974), to be relatively "basal in the lineage of Leiolopisma type skinks" (Hardy, 1977), or to be a member of Cyclodina (Cogger, 1986; Greer, 1989; Hickson et al., 1992). We were not able to include in our study another enigmatic Pacific species, Lieolopisma alazon from Fiji, which has previously been conjectured to be related to the New Zealand skinks (Zug, 1985; Hutchinson et al., 1990).

\subsection{Endemic New Caledonian skink genera}

Our analysis suggests that the New Zealand skinks + "Oligosoma" lichenigera render the New Caledonian clade paraphyletic. However, we cannot statistically reject the hypothesis of New Caledonian monophyly. There is strong support for the monophyly of each of the endemic New Caledonian genera sampled except Lioscincus. The polyphyly of this genus was suspected by Hutchinson et al. (1990) and acknowledged by Bauer and Sadlier (1993, 2000). Lioscincus steindachneri (type species) and L. vivae form a well supported clade nested deep inside the main New Caledonian lineage. Lioscincus nigrofasciolatus clusters not with these taxa, but with a clade including the monotypic Lacertoides + Phoboscinus garnieri. Although not included in our analysis, Lioscincus greeri, is almost certainly the sister group to L. nigriofasciolatus based on morphological similarities (Böhme, 1979; Sadlier, 1986; Bauer and Sadlier, 2000). The remaining species of Lioscincus form two lineages L. tillieri $+L$. maruia and the distinctive 
L. novocaledonicus which, with the New Zealand taxa, form a polytomy, but this larger clade receives no support. It is clear that at least two new genera need to be erected in order to accommodate those species not part of the monophyletic group that includes the type species of Lioscincus, L. steindachneri. However, this will require detailed diagnoses based on morphological data and will be dealt with in a subsequent publication.

Within the main New Caledonian clade, the diminutive fossorial skinks of the genus Nannoscincus are the sister to remaining taxa. The monophyly of the New Caledonian Nannoscincus was previously demonstrated by Sadlier (1990). Sadlier et al. (2002) identified two lineages within the genus, the gracilis group and the mariei group, the latter with the loss of the left oviduct in females. In our analysis, the gracilis group is well supported, but the mariei group is not (see also Sadlier et al., 2004), and the namesake species in both groups are themselves non-monophyletic. Several new species have recently been described within the genus (Sadlier et al., 2004, 2006) and a species level revision is in progress.

Sigaloseps, with two recognized species is weakly supported as the sister group to Celatiscincus + Lioscincus sensu stricto. Celatiscincus (type species Lygosoma euryotis, Werner) was previously placed in Marmorosphax (Sadlier, 1986), but later removed from this genus and left incertae sedis by Bauer and Sadlier (2000). Sadlier et al. (2006) erected a new genus for the one known species and described a second, cryptic form, $C$. similis, from the northern Grande Terre. Celatiscincus and Lioscincus have not previously been hypothesized to be closely related, however, all constituent taxa are chiefly mesic-adapted forest species. Both species of Sigaloseps are restricted to the extensive southern ultramafic block in New Caledonia (Bauer and Sadlier, 2000). Sigaloseps deplanchei is widespread in southern New Caledonia, whereas $S$. ruficauda is restricted to the summit areas of Mt. Ouin and Mt. Mou. The former species is currently under investigation in a fine scaled analysis to determine if it may be a composite of several cryptic species.

Lioscincus nigrofasciolatus is the sister to Lacertoides + Phoboscincus garnieri. Although these are all large, strongly-limbed, long-tailed species, they have not previously been suggested as allies. Indeed, Sadlier and Bauer (1999b) suggested that L. tillieri and Tropidoscincus might be allied to Lacertoides, based chiefly on their shared possession of exceedingly long tails. Phoboscincus bocourti has recently been rediscovered after more than a century (Ineich, 2004) and it will be intriguing to place it in its phylogenetic context as there is some morphological evidence that it may not be congeneric with $P$. garnieri.

Marmorosphax and Kanakysaurus are sister taxa, with weak support. The two genera are similar in appearance and both are viviparous, a feature otherwise found in New Caledonia only in Lioscincus tillieri (Sadlier et al., 2004). Marmorosphax is a monophyletic clade that includes one widespread member, M. tricolor, and several new taxa from isolated ultramafic peaks in the northwest of the island (Sadlier et al., in press), and the southern ultramafic endemic, M. montana.

Tropidoscincus are large, terrestrial skinks with long limbs and tails and have previously been interpreted as potentially allied to Lacertoides and Lioscincus tillieri (Sadlier and Bauer, 1999b) in sharing exceptionally long tails. The most distinctive member of the genus, T. aubrianus, is the sister to the other two species. Extensive sampling within $T$. boreas and $T$. variabilis, suggests that the latter may be paraphyletic, but this requires further investigation. Tropidoscincus is the sister group to the most surprising clade of New Caledonian skinks. This includes the monotypic Graciliscincus and Simiscincus, a new genus (to be described elsewhere) and Caledoniscincus, the most widespread and speciose genus in New Caledonia. The former two genera are fossorial and restricted to the southern portion of New Caledonia and the third is known only from a single ultamafic peak in the northwest of the island, whereas the latter is terrestrial, heliophilic, and occurs throughout New Caledonia, its offshore islands (Bauer et al., 1992; Bauer and Sadlier, 1994; Sadlier and Bauer, 1997a) and southern Vanuatu (Medway and Marshall, 1975), from the intertidal zone (Bauer and DeVaney, 1987) to elevations of over $1000 \mathrm{~m}$. Relationships among these genera are poorly resolved, but the diverse Caledoniscincus is strongly supported as monophyletic. Although there are areas of conflict, our data are consistent with the sistergroup pairing C. auratus $-C$. renevieri retrieved using allozyme data (Sadlier et al., 1999). A more extensive analysis of this genus (Sadlier, Smith, Bauer, in prep.) reveals that some morphological species include cryptic forms and that species boundaries within Caledoniscincus need to be reevaluated.

The only genus not included in the analysis was Geoscincus, known only from the two types of $G$. haraldmeieri. Although Böhme (1976) and Börner (1980) suggested that this species was related to Phoboscincus, there is no objective basis for this, and its affinities remain uncertain.

\subsection{Biogeographic history of the Tasmantis skinks}

Evidence for biotic relationships of vicariant origin between Australia on one hand and New Caledonia + New Zealand on the other are supported by a variety of taxa (Cracraft, 1980). Dating of the trans-Tasman split between Australian and New Caledonian diplodactylid geckos is supportive of a Gondwanan origin for this group (King, 1987; Bauer, 1990), although the modern New Caledonian radiation of geckos probably dates only from the Oligocene (Jackman, 2005), perhaps reflecting a major faunal turnover associated with ultramafic overthrusting during this period (Cluzel et al., 2001; Bauer et al., 2006).

Although Adler et al. (1995) suggested that the New Caledonian skink fauna might be a relict of ancient Gondwanan connections, Sadlier (1986) and Bauer and Sadlier $(1993,2000)$ proposed over-water dispersal for the 
colonization of the region, but considered that the extreme morphological diversity amongst the endemic genera argued against a Pliocene origin, as had been assumed by many herpetologists for the endemic skinks of New Zealand (see below).

Although our data do support the monophyly of the endemic skinks of the Tasmantis block, they do not imply Gondwanan relationships or a vicariant origin of the regional scincid fauna. Our two methods of age estimation differ significantly from one another, yielding a range of possible divergences of the Tasmantis lineage from other Eugongylus group skinks from 12.7 to $40.7 \mathrm{Myr}$. If the true age of this split is closer to the upper limit it would be consistent with the estimate of Hickson et al. (2000) of at least $23 \mathrm{Myr}$ for the age of Oligosoma, whereas the lower estimate is compatible with the estimate of a maximum of $17 \mathrm{Myr}$ since the divergence of Leiolopisma from the rest of the Eugongylus group (Austin and Arnold, 2006). Both of these estimates are based on $12 \mathrm{~S}$ sequences. However, the estimate of the age of Oligosoma is calibrated using bovids and ratites aged between 28 and $19 \mathrm{Myr}$, and the Leiolopisma date is based on a calibration point in the scincine genus Chalcides at $1 \mathrm{Myr}$. We believe that a younger date is more likely correct based on two main lines of evidence. First, a recent chronogram of squamate reptiles (Wiens et al., 2006) suggests that the $20-23 \mathrm{Myr}$ date for Pygopus (Jennings et al., 2003) used as a calibration point to estimate rates of sequence evolution may be overestimated by a factor of 2. Second, older dates imply overwater colonization during periods of minimal emergent land in the southwest Pacific and also imply the divergence of Oligosoma lichenigera from New Zealand skinks long before the emergence of Lord Howe Island (see below). Consequently, we base our biogeographic hypotheses on a Miocene origin of the Tasmantis group of skinks.

Our data strongly support the hypothesis that New Caledonia was colonized, probably only once, by Eugongylus group skinks during the Middle Miocene. This was a period of uplift and marine regression in New Caledonia which followed a period of Oligocene marine transgressions, which reduced neighboring New Zealand to an area of about $18 \%$ of its current aerial land mass (Cooper and Millener, 1993) and may have submerged the majority of New Caledonia (Murienne et al., 2005).

A lack of resolution at the base of the Eugongylus group phylogeny precludes identification of a probable source of this colonization. However, emergent seamounts along the Norfolk Ridge may have provided an ephemeral link between portions of the Outer Melanesian Arc and New Caledonia during parts of the Miocene (Holloway, 1979; Herzer et al., 1997; Waters et al., 2000; Swenson et al., 2001) and the Queensland Rise, roughly in the middle of the Coral Sea, may have offered stepping stones from Australia during periods of lowered sea levels (Raven and Axelrod, 1972).

In contrast to earlier interpretations of the New Caledonian fauna (e.g., Diamond, 1984), there now exists clear evi- dence that New Caledonia has been the site of numerous in situ radiations of vertebrate taxa (Bauer, 1989; Bauer and Sadlier, 1993, 2000; Adler et al., 1995). Indeed, animals and plants of many groups exhibit significant radiations within New Caledonia (e.g., Haase and Bouchet, 1998; Eibl et al., 2001). Our data suggest that the modern generic diversity of New Caledonian skinks was established shortly after the colonization of the island, and the lack of support for most patterns of intergeneric relationships may be a reflection of a relatively explosive radiation of adaptive types. Speciation within the endemic genera has probably been influenced by significant climatic and vegetational changes that characterized major portions of the later Tertiary (Lowry, 1998; Lee et al., 2001), but specific candidate cladogenetic events remain elusive. In most instances, however, there is no evidence of adaptive intrageneric radiations with significant anagenetic change. Rather, speciation appears to have been the result of fragmentation, yielding morphologically and ecologically similar congeners in allopatry.

Our data also strongly suggest a monophyletic origin (based on our limited sampling) of the New Zealand plus Lord Howe/Norfolk Island Eugongylus group skinks, probably from New Caledonia (although a sister group relationship to the New Caledonian clade cannot be rejected). Caughley (1964) proposed two invasions of New Zealand from Australia, and Whitaker (1968) proposed three, while Towns (1974) suggested that New Caledonia might have been a source area for the New Zealand fauna. Hardy (1977) also proposed multiple invasions of New Zealand from New Caledonia, but also believed that at least some Leiolopisma (now Oligosoma) in New Zealand had arrived overwater from Australia. He also proposed the independent derivation of $O$. lichenigera from eastern Australia. Our data contradict this scenario and confirm that this lineage is considerably older than Hardy (1977) had supposed. Based on our lower age estimates the split between "Oligosoma" lichenigera and the endemic New Zealand clade took place approximately 7.9 Myr. This corresponds well to the $7 \mathrm{Myr}$ estimate for the age of Lord Howe Island (McDougall et al., 1981; Pickard, 1983). The younger (2.3-3.0 Myr) age of Norfolk Island (Jones and McDougall, 1973; Otte and Rentz, 1985) suggests that colonization was by way of Lord Howe, although our sampling did not permit us to test this.

Earlier estimates placed the origin of the New Zealand skinks in the Pliocene (Robb, 1973; Towns, 1974; Bull and Whitaker, 1975; Hardy, 1977). More recent allozyme (Towns et al., 1985; Daugherty et al., 1990) and mtDNA sequencebased studies (Hickson et al., 2000) have estimated the age of the New Zealand skink fauna to be $20 \mathrm{Myr}$ or more. If our preferred (younger) age estimate is correct, it suggests that the New Zealand OligosomalCyclodina clade is less than $7 \mathrm{Myr}$ old. This is far younger than the estimate of Hickson et al. (2000), but consistent with estimates for the diversification of a variety of other elements of the New Zealand biota (Chambers et al., 2001; Trewick and Wallis, 2001; Trewick and Morgan-Richards, 2005). 
Although our sampling is insufficient to suggest either a source or the timing of the colonization of the New Caledonian region by Emoia loyaltiensis, E. cyanura, or Cryptoblepharus novocaledonicus, it is likely that these events were very recent. Emoia cyanura is widespread in the tropical Pacific (Brown, 1991) and C. novocaledonicus exhibits almost no genetic variability across its range in New Caledonia (Smith et al., unpublished) and is very similar to congeneric populations elesewhere, particularly in Vanuatu (G. Zug, pers. commun.). Further, both species of Emoia are limited in their New Caledonian distribution to the Loyalty Islands, which have been emergent only since the Pleistocene (Paris, 1981).

As no modern geological reconstructions of the late Tertiary history of the southwest Pacific support the existence of direct land connections among the components of the Tasmantis block, or between this unit and either Australia or elements of the Outer Melanesian Arc islands, we are able to reject vicariant hypotheses regarding the origin of the skinks of the region. Each island group was colonized over water, almost certainly in the order New CaledoniaLord Howe Island - New Zealand, with a subsequent colonization of Norfolk Island from Lord Howe in the last 3 Myr. Deeper sampling of the Australian, New Guinean and other Melanesian Eugongylus group lineages may eventually clarify the probable source area for this diverse clade of skinks and finer scaled sampling within New Caledonia and especially New Zealand may shed light on patterns of "continental" speciation and radiation in these islands.

\section{Acknowledgments}

We thank Tony Whitaker, Wolfgang Böhme, Jeremy Austin, and Charles Daugherty for providing some of the tissue samples used in this study. We are indebted to the New Caledonian authorities for their continued support of our herpetological research. Our collecting and export of New Caledonain skinks has been authorized under a number of permits issued to the authors over a period of more than 20 years. We particularly thank Jean-Jérome Cassan, Anne-Claire Goarant, Richard Farman, Joseph Manauté and Cendrine Meresse in this regard. Permission to access various sites was granted by a large number of private land owners, municipal and commune governments and mining companies, most notably SLNSociété Le Nickel and SMSP-Société Minière du Sud Pacifique. We acknowledge the collecting efforts of our colleagues Tony and Vivienne Whitaker, Glenn Shea, and Jennifer Wright-Bourque. Invaluable support was provided in Nouméa by Jean Chazeau and Hervé Jourdan of IRD. This research was supported by Grants DEB 0108108 and DEB 0515909 from the National Science Foundation to A.M. Bauer and T. Jackman. This research was funded in part by National Science Foundation Grants DEB 0445213 and DBI 0400797 to C.C. Austin. The manuscript was improved by comments from two anonymous reviewers.

\section{References}

Adler, G.H., Austin, C.C., Dudley, R., 1995. Dispersal and speciation of skinks among archipelagos in the tropical Pacific Ocean. Evol. Ecol. 9, 529-541.

Arnold, E.N., 1980. Recently extinct reptile populations from Mauritius and Reunion, Indian Ocean. J. Zool., London 191, 33-47.

Austin, J.J., Arnold, E.N., 2006. Using ancient and recent DNA to explore relationships of extinct and endangered Leiolopisma skinks (Reptilia: Scincidae) in the Mascarene islands. Mol. Phylogenet. Evol. 39, 503-511.

Bauer, A.M., 1989. Reptiles and the biogeographic interpretation of New Caledonia. Tuatara 30, 39-50.

Bauer, A.M., 1990. Phylogenetic systematics and biogeography of the Carphodactylini (Reptilia: Gekkonidae). Bonn. Zool. Monogr. 30, 1-220.

Bauer, A.M., 1999. The terrestrial reptiles of New Caledonia: the origin and evolution of a highly endemic herpetofauna. In: Ota, H. (Ed.), Tropical Island Herpetofauna: Origin, Current Diversity, and Conservation. Elsevier, Amsterdam, pp. 3-25.

Bauer, A.M., DeVaney, K.D., 1987. Aspects of diet and habitat use in some New Caledonian lizards. Amphibia-Reptilia 8, 349-364.

Bauer, A.M., Sadlier, R.A., 1993. Systematics, biogeography and conservation of the lizards of New Caledonia. Biodiv. Lett. 1, 107-122.

Bauer, A.M., Sadlier, R.A., 1994. The terrestrial herpetofauna of the Ile des Pins, New Caledonia. Pacific Sci. 48, 353-366.

Bauer, A.M., Sadlier, R.A., 2000. The Herpetofauna of New Caledonia. Society for the Study of Amphibians and Reptiles, Ithaca.

Bauer, A.M., Renevier, A., Sadlier, R.A., 1992. Caledoniscincus austrocaledonicum (Reptilia: Scincidae) from Ile Surprise, d'Entrecasteaux Reefs, New Caledonia. Pacific Sci. 46, 86-89.

Bauer, A.M., Jackman, T., Sadlier, R.A., Whitaker, A.H., 2006. A revision of the Bavayia validiclavis group (Squamata: Gekkota: Diplodactylidae), a clade of New Caledonian geckos exhibiting microendemism. Proc. California Acad. Sci. 57, 503-547.

Bavay, A., 1869. Catalogue des reptiles de la Nouvelle-Calédonie et description d'espèces nouvelles. Mém. Soc. Linn. Normandie 15, 1-37.

Berry, O., Gleeson, D.M., Sarre, S.D., 2003. Microsatellite DNA markers for New Zealand skinks. Conserv. Genet. 4, 411-414.

Bocage, J.V., Barboza, du., 1873. Sur quelques sauriens nouveaux de la Nouvelle Calédonie et de l'Australie. J. Sci. Math. Phys. Nat. Lisboa 4, 228-232.

Böhme, W., 1976. Über die Gattung Eugongylus Fitzinger, mit Beschreibung einer neuer Art (Reptilia: Scincidae). Bonn. Zool. Beitr. 27, 245-251.

Böhme, W., 1979. Eine neue Art der Gattung Leiolopisma Duméril et Bibron, 1839 aus Neukaledonien (Reptilia: Sauria: Scincidae). Salamandra $15,140-145$.

Börner, A.-R., 1980. Über neukaledonische Skinke des Leiolopisma austrocaledonicum -Komplexes. Misc. Art. Saurol. 5, 1-15.

Boulenger, G.A., 1887. Catalogue of the Lizards in the British Museum (Natural History), Second Edition. Vol. 3. Lacertidae, Gerrhosauridae, Scincidae, Anelytropidae, Dibamidae, Chamaeleonidae. British Museum (Natural History), London.

Brandley, M.C., Schmitz, A., Reeder, T.W., 2005. Partitioned Bayesian analysis, partition choice, and the phylogenetic relationships of scincid lizards. Syst. Biol. 54, 373-390.

Brown, W.C., 1991. Lizards of the genus Emoia (Scincidae) with observations on their evolution and biogeography. Mem. Calif. Acad. Sci. 15, vi +94.

Brown, K.S., 1999. Deep Green rewrites evolutionary history of plants. Science 285, 990-991.

Buckley, T.R., Arensburger, P., Simon, C., Chambers, G.K., 2002. Combined data, Bayesian phylogenetics, and the origin of the New Zealand cicada genera. Syst. Biol. 51, 4-18.

Bull, P.C., Whitaker, A.H., 1975. The amphibians, reptiles, birds and mammals. In: Kuschel, G. (Ed.), Biogeography and Ecology in New Zealand. Dr. W. Junk, The Hague, pp. 231-276.

Caughley, G., 1964. Does the New Zealand vertebrate fauna conform to zoogeographic principles? Tuatara 12, 49-58.

Chambers, G.K., boon, W.M., Buckley, T.R., Hitchmough, R.A., 2001. Using molecular methods to understand the Gondwanan affinities of the New Zealand biota: three case studies. Austral. J. Bot. 49, 377-387. 
Chazeau, J., 1993. Research on New Caledonian terrestrial fauna: achievements and prospects. Biodiv. Lett. 1, 123-129.

Cluzel, D., Aitchison, J.C., Picard, C., 2001. Tectonic accretion and underplating of mafic terranes in the Late Eocene intraoceanic fore-arc of New Caledonia (Southwest Pacific): geodynamic implications. Tectonophysics 340, 23-59.

Cogger, H.G., 1979. Reptiles and Amphibians of Australia, 2nd ed. Reed, Sydney.

Cogger, H.G., 1986. Reptiles and Amphibians of Australia, fourth ed. Reed, Sydney.

Cogger, H.G., 1992. Reptiles and Amphibians of Australia, 5th ed. Reed Books, Chatswood, NSW

Coleman, P.J., 1980. Plate tectonics background to biogeographic development in the southwest Pacific over the last 100 million years. Paleogeogr., Paleoclimatol., Paleoecol. 31, 105-121.

Cooper, R.A., Millener, P.R., 1993. The New Zealand biota: historical background and new research. Trends Ecol.Evol. 8, 429-433.

Cracraft, J., 1980. Biogeographic patterns of terrestrial vertebrates in the southwest Pacific. Paleogeogr., Paleoclimatol., Paleoecol. 31, 353-369.

Czechura, G.V., 1981. The rare scincid lizard, Nannoscincus graciloides: a reappraisal. J. Herpetol. 15, 315-320.

Daugherty, C.H., Patterson, G.B., Thorn, C.J., French, D.C., 1990. Differentiaon of the members of the New Zealand Leiolopisma nigriplantare species complex (Lacertilia: Scincidae). Herpetol. Monogr. 4, 61-76.

Daugherty, C.H., Gibbs, G.W., Hitchmough, R.A., 1993. Mega-island or micro-continent? New Zealand and its fauna. Trends Ecol. Evol. 8, 437-442.

Daugherty, C.H., Patterson, G.B., Hitchmough, R.A., 1994. Taxonomic and conservation review of the New Zealand herpetofauna. N. Zealand J. Zool. 21, 317-323.

Diamond, J., 1984. Biogeographic mosaics in the Pacific. In: Radovsky, F.J., Raven, P.H., Sohmer, S.H. (Eds.), Biogeography of the Tropical Pacific. Bishop Museum Special Publication, 72, pp. 1-14.

Donnellan, S.C., 1985. The evolution of sex chromosomes in scincid lizards. Ph.D. dissertation, Macquarie University.

Driskell, A.C., Ané, C., Burleigh, J.G., McMahon, M.M., O’Meara, B.C., Sanderson, M.J., 2004. Prospects for building the Tree of Life from large sequence databases. Science 306, 1172-1174.

Eibl, J.M., Plunkett, G.M., Lowry, P.P., II, 2001. Evolution of Polyscias sect. Tieghemopanax (Araliaceae) based on nuclear and chloroplast DNA sequence data. Adansonia, sér. 3 23, 23-48.

Felsenstein, J., 1985. Confidence limits on phylogenies: an approach using the bootstrap. Evolution 39, 783-791.

Greer, A.E., 1970. A subfamilial classification of scincid lizards. Bul. Mus. Comp. Zool. 139, 151-184.

Greer, A.E., 1974. The generic relationships of the scincid lizard genus Leiolopisma and its relatives. Austral. Jour. Zool. Suppl. Ser. 31, 1-67.

Greer, A.E., 1979. A phylogenetic subdivision of Australian skinks. Rec. Austral. Mus. 32, 339-371.

Greer, A.E., 1980. A new species of Morethia (Lacertilia: Scincidae) from Northern Australia, with comments on the biology and relationships of the genus. Rec. Austral. Mus. 33, 89-122.

Greer, A.E., 1989. The Biology and Evolution of Australian Lizards. Surrey Beatty and Sons Pty., Ltd., Chipping Norton, NSW.

Greer, A.E., 1990. Overlap pattern in the preanal scale row: an important systematic character in skinks. J. Herpetol. 24, 328-330.

Groth, J.G., Barrowclough, G.F., 1999. Basal divergences in birds and the phylogenetic utility of the nuclear RAG-1 gene. Mol. Phylogenet. Evol. $12,115-123$.

Günther, A., 1872. On some new species of reptiles and fishes collected by J. Brenchley. Esq. Ann. Mag. Natur. Hist. (41), 418-420.

Günther, A., 1873. Reptiles. In: Brenchly, J.L. (Ed.), Jottings During the Cruise of H.M.S. Curaçoa Among the South Sea Islands in 1865. Longmans, Green and Co., Germany, pp. 396-407.

Haase, M., Bouchet, P., 1998. Radiation of crenobiontic gastropods on an ancient continental island: the Hemistomia-clade in New Caledonia (Gastropoda: Hydrobiidae). Hydrobiologia 367, 43-129.
Hall, R., 1997. Cenozoic tectonics of SE Asia and Australasia. In: Howes, J.V.C., Noble, R.A. (Eds.), Proceedings IPA Petroleum Systems of SE Asia and Australasia Conference. Jakarta, pp. 47-62.

Hardy, G.S., 1977. The New Zealand Scincidae (Reptilia: Lacertilia); a taxonomic and zoogeographic study. New Zealand J. Zool. 4, 221-325.

Herzer, R.H., Chaproniere, G.C.H., Edwards, A.R., Hollis, C.J., Pelletier, B., Raine, J.I., Scott, G.H., Stagpoole, V., Strong, C.P., Symonds, P., Wilson, J.G., Zhu, H., 1997. Seismic stratigraphy and structural history of the Reinga Basin and its margins, southern Norfolk Ridge System. New Zealand J. Geol. Geophys. 40, 425-451.

Hickson, R.E., Penny, D., Scott, D.B., 1992. Molecular systematics and evolution in New Zealand: applications to cryptic skink species. New Zealand J. Zool. 19, 33-44.

Hickson, R.E., Slack, K.E., Lockhart, P., 2000. Phylogeny recapitulates geography, or why New Zealand has so many species of skinks. Biol. J. Linn. Soc. 70, 415-433.

Holloway, J.D., 1979. A Survey of the Lepidoptera, Biogeography and Ecology of New Caledonia. Dr. W. Junk, The Hague.

Honda, M., Ota, H., Kobayashi, M., Hikida, T., 1999. Phylogenetic relationships of Australian skinks of the Mabuya group (Reptilia: Scincidae) inferred from mitochondrial DNA sequences. Genes Genet. Syst. $74,135-139$.

Honda, M., Ota, H., Kobayashi, M., Nabhitabhata, J., Yong, H.-S., Hikida, T., 2000. Phylogenetic relationships, character evolution, and biogeography of the subfamily Lygosominae (Reptilia: Scincidae) inferred from mitochondrial DNA sequences. Molec. Phylogenet. Evol. 15, $452-461$

Honda, M., Ota, H., Köhler, G., Ineich, I., Chirio, L., Chen, S.-L., Hikida, T., 2003. Phylogeny of the lizard subfamily Lygosominae (Reptilia: Scincidae), with special reference to the origin of the New World taxa. Genes Genet. Syst. 78, 71-80.

Huelsenbeck, J.P., Ronquist, F., 2001. MrBayes: Baysian inference of phylogeny. Bioinformatics 17, 754-755.

Hutchinson, M.N., 1993. Family Scincidae. In: Glasby, C.J., Ross, G.J.B., Beesley, P.L. (Eds.), Fauna of Australia, vol. 2A. Amphibia and Reptilia. Australian Government Printing Service, Canberra, pp. 261-279.

Hutchinson, M.N., Donnellan, S.C., 1993. Biogeography and phylogeny of the Squamata. In: Glasby, C.J., Ross, G.J.B., Beesley, P.L. (Eds.), Fauna of Australia vol. 2A. Amphibia and Reptilia Australian Government Publishing Service, Canberra, pp. 210-220.

Hutchinson, M.N., Donnellan, S.C., Baverstock, P.R., Krieg, M., Simms, S., Burgin, S., 1990. Immunological relationships and generic revision of the Australian lizards assigned to the genus Leiolopisma (Scincidae: Lygosominae). Austral. J. Zool. 38, 535-554.

Ineich, I., 2004. Le squinque terrifiant de Bocourt retrouvé en NouvelleCalédonie. Press release, Muséum national d'histoire naturelle, Paris, 3 Mars 2004.

Jackman, T., 2005. Tempo and mode of diversification of endemic New Caledonian lizards. Abstracts, 2005 Joint Meeting of Ichthyologists and Herpetologists, Tampa, Florida, 243.

Jaffré, T., Bouchet, P., Veillon, J.-M., 1998. Threatened plants of New Caledonia: is the system of protected areas adequate? Biodiv. Conserv. 7, $109-135$.

Jones, J.G., McDougall, J., 1973. Geological history of Norfolk and Philip Islands, southwest Pacific Ocean. J. Geol. Soc. Austral. 20, 239-257.

King, M., 1987. Origin of the Gekkonidae: chromosomal and albumin evolution suggests Gondwanaland. Search 18, 252-254.

Kroenke, L.W., 1984. Cenozoic tectonic development of the southwest Pacific. United Nations Economic and Social Commission, Committee for Coordination of Joint Prospecting for Mineral Resources in the South Pacific Offshore Area. Tech. Bull. 6, 1-122.

Kroenke, L.W., 1996. Plate tectonic development of the western and southwestern Pacific: Mesozoic to the present. In: Keast, A., Miller, S.E. (Eds.), The Origin and Evolution of Pacific Island Biotas. In: New Guinea to Eastern Polynesia: Patterns and Processes SPB Academic Publishing, Amsterdam, pp. 19-34.

Lee, D.E., Lee, W.G., Mortimer, N., 2001. Where and why have all the flowers gone? Depletion and turnover in the New Zealand Cenozoic 
angiosperm flora in relation to palaeogeography and climate. Austral. J. Bot. 49, 341-356.

Lowry, P.P. II., 1998. Diversity, endemism, and extinction in the flora of New Caledonia: a review. In: Peng, C.I., Lowry, P.P., II (Eds.), Rare, Threatened, and Endangered Floras of Asia and the Pacific Rim. Institute of Botany, Academia Sinica Monograph Series No. 16. Taipei, pp. 181-206.

Lowry, P.P. II., Munzinger, J., Bouchet, P., Géraux, H., Bauer, A.M., Langrand, O., Mittermeier, R.A., 2004. New Caledonia. In: Mittermeier, R.A., Gil, P.R., Hoffmann, M., Pilgrim, J., Brooks, T., Mittermeier, C.G., Lamoreux, J., Da Fonseca, G.A.B. (Eds.), Hotspots Revisited. CEMEX, Mexico City, pp. 192-197.

Macey, J.R., Larson, A., Ananjeva, N.B., Papenfuss, T.J., 1997. Evolutionary shifts in three major structural features of the mitochondrial genome among iguanian lizards. J. Mol. Evol. 44, 660-674.

Macey, J.R., Schulte II, J.A., Ananjeva, N.B., Larson, A., Rastegar-Pouyani, N., Shammakov, S.M., Papenfuss, T.J., 1998. Phylogenetic relationships among agamid lizards of the Laudakia caucasia species group: testing hypotheses of biogeographic fragmentation and an area cladogram for the Iranian Plateau. Mol. Phylogenet. Evol. 10, 118-131.

McDougall, I., Embleton, B.J.J., Stone, D.S., 1981. Origin and evolution of Lord Howe Island-South-west Pacific Ocean. J. Geol. Soc. Austral. 28, 156-176.

Medway, Lord., Marshall, A.G., 1975. Terrestrial vertebrates of the New Hebrides: origin and distribution. Phil. Trans. Roy. Soc. London 272, 423-465.

Mittermeier, R.A., Werner, T.B., Lees, A., 1996. New Caledonia-a conservation imperative for an ancient land. Oryx 30, 104-112.

Mittleman, M.B., 1952. A generic synopsis of the lizards of the subfamily Lygosominae. Smithsonian Misc. Coll. 117 (17), 1-35.

Morat, P., 1993. Our knowledge of the flora of New Caledonia: endemism and diversity in relation to vegetation types and substrates. Biodiv. Lett. 1, 72-81.

Morat, P., Jaffré, T., Veillon, J.-M., MacKee, H.S., 1986. Affinités floristiques et considérations sur l'origine des maquis miniers de la Nouvelle-Calédonie. Bull. Mus. Natl. Hist. Nat., Paris, $4^{e}, 8$, sect. B, Adansonia ${ }^{\circ} 2,133-182$.

Murienne, J., Grandcolas, P., Piulachs, M.D., Bellés, X., D’Haese, C., Legendre, F., Pellens, R., Guilbert, E., 2005. Evolution on a shaky piece of Gondwana: is local endemism recent in New Caledonia ? Cladistics 21, 2-7.

Myers, N., 1988. Threatened biotas: "hot spots" in tropical forests. The Environmentalist 8, 187-208.

Myers, N., 1990. The biodiversity challenge: expande hot-spot analysis. The Environmentalist 10, 243-256.

Myers, N., Mittermeier, R.A., Mittermeier, C.G., da Fonseca, G.A.B., Kent, J., 2000. Biodiversity hotspots for conservation priorities. Nature 403, 853-858.

Nylander, J.A. 2004. MrModelTest. 2.0. Distributed by the author. Evolutionary Biology Centre, Uppsala University, Uppsala.

Nylander, J.A.A., Ronquist, F., Huelsenbeck, J.P., Nieves-Aldrey, J.L., 2004. Bayesian phylogenetic analysis of combined data. Syst. Biol. 53, $47-67$.

Otte, D., Rentz, D.C.F., 1985. The crickets of Lord Howe and Norfolk Islands (Orthoptera, Gryllidae). Proc. Acad. Nat. Sci. Philadelphia 137, 79-101.

Paris, J.P., 1981. Géologie de la Nouvelle-Calédonie. Mém. Bur. Rech. Géol. Minières 113, 1-278. 2 maps.

Patterson, G.B., Daugherty, C.H., 1990. Four new species and one new subspecies of skinks, genus Leiolopisma (Reptilia: Lacertilia: Scincidae) from New Zealand. J. Roy. Soc. New Zealand 20, 65-84.

Patterson, G.B., Daugherty, C.H., 1995. Reinstatement of the genus Oligosoma (Reptilia: Lacertilia: Scincidae). J. Roy. Soc. New Zealand 25, 327-331.

Penny, N.D., 1975. Evolution of extant Mecoptera. J. Kansas Entomol. Soc. 40, 331-350.

Peters, W., 1869. Über neue Gattungen und neue oder weniger bekannte Arten von Amphibien Monatsber. Königl. Preuss. Akad. Wiss., Berlin. pp. $432-445,1$ pl..
Peters, W., 1879. Über Sauroscincus, eine neue Gattung von Scincoiden, aus Neu-Caledonien. Sber. Ges. Naturf. Freunde Berlin 1879, 149-150.

Phillipe, H., Snell, E.A., Bapteste, E., Lopez, P., Holland, P.W.H., Casane, D., 2004. Phylogenomics of eukaryotes: impact of missing data on large alignments. Mol. Biol. Evol. 21, 1740-1752.

Pickard, J., 1983. Vegetation of Lord Howe Island. Cunninghamia 1, 133-266.

Platnick, N.I., 1993. The araneomorph spider fauna of New Caledonia. Biodiv. Lett. 1, 102-106.

Polhemus, D.A., 1996. Island arcs and their influence on Indo-Pacific biogeography. In: Keast, A., Miller, S.E. (Eds.), The origin and evolution of pacific island biotas, New Guinea to Eastern Polynesia: Patterns and Processes. SPB Academic Publishing, Amsterdam, pp. 51-66.

Rambaut, A., 1995. Se-Al. Sequence Alignment Editor, Evolutionary Biology Group. University of Oxford, Oxford.

Raven, P.H., Axelrod, D.I., 1972. Plate tectonics and Australasian paleobiogeography. Science 176, 1379-1386.

Reeder, T.W., 2003. A phylogeny of the Australian Sphenomorphus group (Scincidae: Squamata) and the phylogenetic placement of the crocodile skinks (Tribolonotus): Bayesian approaches to assessing congruence and obtaining confidence in maximum likelihood inferred relationships. Mol. Phylogenet. Evol. 27, 384-397.

Robb, J., 1973. Reptiles and amphibians. In: Williams, G.R. (Ed.), The Natural History of New Zealand: An Ecological Survey. Reed, Wellington, pp. 285-303.

Roux, J., 1913. Les reptiles de la Nouvelle-Calédonie et des Îles Loyalty. In: Sarasin, F., Roux, J. (Eds.), Nova Caledonia, Zoologie, vol. 1(2). C.W. Kreidels Verlag, Wiesbaden, pp. 79-160.

Sadlier, R.A., 1986. A review of the scincid lizards of New Caledonia. Rec. Austral. Mus. 39, 1-66.

Sadlier, R.A., 1990. The scincid lizard genus Nannoscincus Günther: a revaluation. Mem. Qld. Mus. 29, 487-494.

Sadlier, R.A., Bauer, A.M., 1997a. The terrestrial herpetofauna of the Loyalty Islands. Pacific Sci. 51, 76-90.

Sadlier, R.A., Bauer, A.M., 1997b. A new genus and species of lizard (Reptilia: Scincidae) from New Caledonia, southwest Pacific. Pacific Sci. 51, 91-96.

Sadlier, R.A., Bauer, A.M., 1999b. The scincid lizard Lioscincus tillieri from New Caledonia in the southwest Pacific: new information on the species biology, distribution, and morphology. Rec. Austral. Mus. 51, 93-98.

Sadlier, R.A., Shea, G.M., Bauer, A.M., 1997. A new genus and species of lizard (Squamata, Scincidae) from New Caledonia, southwest Pacific. Zool. Neocaledonia 4. Mém. Mus. Natl. Hist. Nat. 171, 379-385.

Sadlier, R.A., Whitaker, A.H., Bauer, A.M., 1998. Lioscincus maruia, a new species of Lizard (Reptilia: Scincidae) from New Caledonia. Southwest Pacific. Pacific Sci. 52, 334-341.

Sadlier, R.A., Bauer, A.M., Colgan, D.J., 1999. The scincid lizard genus Caledoniscincus (Reptilia: Scincidae) from New Caledonia in the southwest Pacific: a review of Caledoniscincus austrocaledonicus (Bavay) and description of six new species from Province Nord. Rec. Austral. Mus. 51, 57-82.

Sadlier, R.A., Bauer, A.M., Whitaker, A.H., 2002. The scincid lizard genus Nannoscincus Günther from New Caledonia in the southwest Pacific: a review of the morphology and distribution of species in the Nannoscincus mariei species group, including the description of three new species from Province Nord. Zool. Neocaledonica 5. Mem. Mus. Natl. Hist. Nat. 187, 269-276.

Sadlier, R.A., Bauer, A.M., Whitaker, A.H., Smith, S.A., 2004. Two new scincid lizards (Squamata: Scincidae) from the Massif de Kopéto, northwestern New Caledonia. Proc. Calif. Acad. Sci. 55, 208-221.

Sadlier, R.A., Smith, S.A., Bauer, A.M., Whitaker, A.H., 2004. A new genus and species of live-bearing scincid lizard (Reptilia: Scincidae) from New Caledonia. J. Herpetol. 38, 320-330.

Sadlier, R.A., Bauer, A.M., Smith, S.A., 2006. A new species of Nannoscincus Günther (Squamata: Scincidae) from high elevation forest in southern New Caledonia. Rec. Austral. Mus. 58, 29-36.

Sadlier, R.A., Smith, S.A., Bauer, A.M., 2006. A new genus for the New Caledonian scincid lizard Lygosoma euryotis Werner 1909, and the description of a new species. Rec. Austral. Mus. 58, 19-28. 
Séret, B., 1997. Les poissons d'eau douce de Nouvelle-Calédonie: implications biogéographiques de récentes découvertes. Mém. Mus. Natl. Hist. Nat., Paris 171, 369-378.

Smith, M.A., 1937. A review of the genus Lygosoma (Scincidae: Reptilia) and its allies. Rec. Indian Mus. 39, 213-234.

Smith, S.A., 2001. A molecular phylogenetic study of the Eugongylus group of skinks. Ph.D. dissertation, University of Adelaide, Adelaide, Australia.

Stevens, G.R., 1980. New Zealand Adrift: The Theory of Continental Drift in a New Zealand Setting. A.H. \& A.H. Reed, Wellington.

Stevens, G.R., 1989. The nature and timing of biotic links between New Zealand and Australia in Mesozoic and early Cenozoic times. In: Crame, J.A. (Ed.), Origins and Evolution of the Antarctic Biota. Geological Society Special Publication 47. Geological Society, London, pp. 141-166.

Swenson, U., Backland, A., McLoughlin, S., Hill, R.S., 2001. Nothofagus biogeography revisited with special emphasis on the enigmatic distribution of subgenus Brassospora in New Caledonia. Cladistics 17, 28-47.

Swofford, D.L., 2002. PAUP*: Phylogenetic Analysis Using Parsimony (* and other methods). Sinauer Associates, Sunderland, MA.

Templeton, A., 1983. Phylogenetic inference from restriction endonuclease cleavage site maps with particular reference to the evolution of humans and the apes. Evolution 37, 221-224.

Thompson, J.D., Gibson, T.J., Plewniak, F., Jeanmougin, F., Higgins, D.G., 1997. The ClustalX windows interface: flexible strategies for multiple sequence alignment aided by quality analysis tools. Nuc. Acids Res. 24, 4876-4882.

Towns, D.R., 1974. Zoogeography of the New Zealand Scincidae. J. Roy. Soc. New Zealand 4, 217-226.

Towns, D.R., Daugherty, C.H., Newman, D.G., 1985. An overview of the ecological biogeography of the New Zealand lizards (Gekkonidae, Scincidae). In: Grigg, G., Shine, R., Ehmann, H. (Eds.), The Biology of Australasian Frogs and Reptiles. Surrey Beatty and Sons Pty., Ltd., Chipping Norton, NSW, pp. 107-115.
Trewick, S.A., Morgan-Richards, M., 2005. After the deluge: mitochondrial DNA indicates Miocene radiation and Pliocene adaptation of tree and giant weta (Orthoptera: Anostostomatidae). J. Biogeogr. 32, 295-309.

Trewick, S.A., Wallis, G.P., 2001. Bridging the "beech-gap": New Zealand invertebrate phylogeography implicates Pleistocene glaciation and Pliocene isolation. Evolution 55, 2170-2180.

Virot, R., 1956. La végetation canaque. Mém. Mus. Natl. Hist. Nat. n.s., B 7, 1-398.

Waters, J.M., López, J.A., Wallis, G.P., 2000. Molecular phylogenetics and biogeography of galaxiid fishes (Osteichthyes: Galaxiidae): dispersal, vicariance, and the position of Lepidogalaxias salamandroides. Syst. Biol. 49, 777-795.

Whitaker, A.H., 1968. Leiolopisma suteri (Boulenger): an oviparous skink in New Zealand. N. Zealand J. Sci. 11, 425-432.

Whiting, A.S., Bauer, A.M., Sites Jr., J.W., 2003. Phylogenetic relationships and limb loss in sub-Saharan African scincine lizards (Squamata: Scincidae). Mol. Phylogen. Evol. 29, 582-598.

Wiens, J.J., 2003. Missing data, incomplete taxa, and phylogenetic accuracy. Syst. Biol. 52, 528-538.

Wiens, J.J., Fetzner, J.W., Parkinson, C.L., Reeder, T.W., 2005. Hylid frog phylogeny and sampling strategies for speciose clades. Syst. Biol. 54, 719-748

Wiens, J.J., Brandley, M.C., Reeder, T.W., 2006. Why does a trait evolve multiple times within a clade? Repeated evolution of snakelike body form in squamate reptiles. Evolution 60, 123 142.

Winterbourn, M.J., 1980. The freshwater insects of Australia and their affinities. Paleogeogr., Paleoclimatol., Paleoecol. 31, 235 249.

Zug, G.R., 1985. A new skink (Reptilia: Sauria: Leiolopisma) from Fiji. Proc. Biol. Soc. Washington 98, 221-231. 